\title{
Analisis Sistem dan Prosedur Penerimaan Pendapatan Asli Daerah Pada Badan Pengelolaan Keuangan dan Aset Daerah Kota Palembang
}

\author{
Hamzani', Muhamad Aryo Arifin ${ }^{2}$, Panca Satria Putra ${ }^{3}$ \\ ${ }^{1}$ Fakultas Ekonomi dan Bisnis Universitas PGRI Palembang, hamzaniriska@gmail.com \\ ${ }^{2}$ Fakultas Ekonomi dan Bisnis Universitas PGRI Palembang, aryo arifin@yahoo.com \\ ${ }^{3}$ Fakultas Ekonomi dan Bisnis Universitas PGRI Palembang, Ppancasatria@gmail.com
}

\begin{abstract}
This study aims to find out how the system and procedures for receiving local revenue are carried out at the Regional Financial and Asset Management Agency of Palembang City. Systems and procedures are stages or revenue streams from data collection to data processing with regional financial management guidelines and government regulations applied so that they can be assessed whether they are appropriate or not.The data that are managed in this study are the systems and procedures for receiving original local revenue that are in the financial management agency and the regional assets of Palembang. Data analysis and discussion were carried out with a descriptive qualitative analysis method, namely by collecting and analyzing theories from various sources and experts as literature, so that these theories were linked to applications that have been applied to the Regional Financial and Asset Management Agency of Palembang City in the admission process.
\end{abstract}

Keywords: System, Procedure, PAD.

\section{ABSTRAK}

Penelitian ini bertujuan untuk mengetahui bagaimana sistem dan juga prosedur penerimaaan pendapatan asli daerah yang dilaksanakan di Badan Pengelolaan Keuangan dan Aset Daerah Kota Palembang. Sistem dan prosedur adalah tahapan atau alur penerimaan pendapatan dari pengumpulan data hingga proses data dengan pedoman pengelolaan keuangan daerah dan peraturan pemerintah yang diterapkan sehingga dapat dinilai apakah sudah sesuai atau belum. Data yang dikelola dalam penelitian ini adalah sistem dan prosedur penerimaan pendapatan asli daerah yang ada di badan pengelolaan keuangan dan aset daerah kota Palembang. Analisis data dan pembahasan dilaksanakan dengan metode analisis deskriptif kualitatif yaitu dengan pengumpulan dan menganalisis teori dari berbagai sumber dan para ahli sebagai literatur, hingga teori-teori tersebut dikaitkan dengan penerapan yang telah diterapkan pada Badan Pengelolaan Keuangan dan Aset Daerah Kota Palembang dalam proses penerimaannya.

Kata kunci: Sistem, Prosedur, PAD.

\section{A. PENDAHULUAN}

Di era sekarang Peraturan keuangan daerah yang ada saat ini, menjadi informasi yang penting dan berguna bagi penggunanya tentang sistem dan prosedur keuangan daerah, sehingga dapat dikumpulkan dan digunakan untuk memberikan informasi mengenai transaksi ekonomi dan keuangan pemerintah kepada pihak eksekutif, yudikatif, dan masyarakat, adanya tuntutan agar terciptanya Good Governance telah menjadi harapan dan keinginan besar masyarakat untuk mencapai tujuan dan cita-cita bangsa dan Negara. Menurut Erlina, dkk (2015), Akuntansi keuangan daerah ini diperlukan sejalan dengan semangat otonomi daerah yang harus mengelola keuangan daerah secara terpisah dari pemerintah pusat dan sekaligus melaporkan hasilnya secara transparan kepada publik, maka akuntabilitas diperlukan karena adanya tanggung jawab dan mandat yang diberikan kepada yang bersangkutan dalam menjalankan amanah tugasnya, sedangkan yang menjadi 
sangat penting untuk dipahami dalam sistem dari keuangan daerah ini yaitu kesesuaian antara peraturan pemerintah dalam penerapannya di lembaga yang bersangkutan, dalam hal ini yaitu pada badan pengelolaan keuangan dan aset daerah kota palembang .

Akuntansi keuangan daerah adalah akuntansi pemerintah yang digunakan untuk mencatat peristiwa ekonomi pada entitas ekonomi di lingkungan pemerintahan daerah, dalam hal ini pemerintah pusat di daerah akan menjalankan sistem yang telah dibuat dan tetap berdasarkan peraturan pemerintah, khususnya pemerintah dalam negeri (permendagri). Sistem pemerintah dalam penerapan keuangan daerah adalah proses penafsiran dan peringkasan kejadian keuangan serta pelaporan keuangan dalam rangka pelaksanaan APBD, dilaksanakan sesuai dengan prinsipprinsip akuntansi yang diterima secara umum.

Dalam penelitian ini fokus hanya pada penerimaan pendapatan asli daerah, yaitu menilai bagaimana sistem dan prosedur penerimaannya dengan acuan pedoman pengelolaan keuangan daerah dan peraturan pemerintah yang berlaku saat ini, sehingga alur penerimaan PAD dapat dinilai dan disesuaikan, selain pada penilaian berdasarkan peraturan dan pedoman, perlu juga penentuan dan penerapan standar akuntansi pemerintah yang baik dalam menjalankan operasional kegiatan penerimaan pendapatan asli daerah.

Dalam penentuan dan penerapan standar akuntansi pemerintah untuk pelaksanaan dan kebijakan yang dipercayakan kepada entitas pelaporan untuk mencapai tujuan yang telah ditetapkan secara periodik, berdasarkan kajian dari peneliti yang telah dilakukan oleh Raisa dkk (2015), dalam penerapan standar akuntansi pemerintah yang ada yaitu pada badan pengelolaan keuangan dan aset daerah Kabupaten Sitaro, tidak ditemukan adanya indikasi apapun dan semua sistem penerimaan pendapatan asli daerah sudah sesuai pada pedoman pengelolaan keuangan daerah, serta penerapan standar akuntansi pemerintah telah dijalankan dengan baik, dengan ini dapat di asumsikan bahwa pengelolaan keuangan daerah tersebut sudah relevan.

Dalam hal ini berdasarkan kajian terdahulu dan berbagai sumber sebagai bahan pertimbangan, maka peneliti ingin menilai apakah penerapan standar akuntansi pemerintah sudah dijalankan dengan baik juga di badan pengelolaan keuangan dan aset daerah kota Palembang, dengan itu dapat diasumsikan dan dinilai apakah pengelolaan keuangan daerah kota Palembang sudah relevan, sebagai titik fokus pada penelitian ini hanya pada penerimaan pendapatan asli daerah nya saja, karena pendapatan asli daerah merupakan unsur yang sangat penting dalam laporan keuangan daerah dan laporan realisasi anggaran sebagai estimasi dalam pengambilan keputusan pemerintah dalam menentukan anggaran biaya belanja daerah yang akan dilaksanakan atau dimasa yang akan datang, sebelum menentukan estimasi anggaran biaya belanja diperlukan sistem dan prosedur yang baik dalam mengatur setiap tahapan penerimaan pendapatan asli daerah.

Badan pengelolaan keuangan daerah merupakan badan yang mengatur dan mengelola aset daerah yang mencakup perencanaan, penatausahaan, pelaporan, dan pertanggung jawaban keuangan daerah, dalam melaksanakan fungsi nya badan pengelolaan keuangan daerah kota Palembang mengusung visi terwujudnya sistem pelayanan yang professional dan sistem pengelolaan keuangan yang transparan dan akuntabel guna mencapai pemerintahan yang bertanggung jawab, maka dari ini sebagai badan yang dibentuk untuk mengelola keuangan daerah khususnya kota 
Palembang, Perlu dibentuk sistem yang baik untuk mengatur kebijakan-kebijakan yang dijalankan dan ditetapkan secara objektif dan berkelanjutan, di era sekarang koordinasi lintas antar wilayah atau lintas sektor dalam pemecahan dan penanganan suatu masalah yang dihadapi sudah sangat mudah dan relevan, serta penyelenggaraan sistem keuangan secara transparan juga sudah diterapkan cukup baik, khususnya pada pengelolaan keuangan daerah yang sering menjadi konsumsi publik, agar semua sektor dapat berjalan secara seksama perlu pemantapan peraturan yang tepat dalam penerapan dan realisasinya, untuk memudahkan pengelola dan pengguna dalam menggunakan informasi keuangan.

Sistem dan prosedur pendapatan asli daerah merupakan unsur yang penting dalam tahap pelaporan realisasi anggaran, pengambilan keputusan dan untuk informasi bagi pengguna dan masyarakat, maka perlu transparansi dalam memberikan informasi keuangan daerah, masyarakat memiliki hak untuk mengetahui secara terbuka dan menyeluruh atas pertanggungjawaban pemerintah dalam pengelolaan sumber daya yang dipercayakan dan ketaatannya pada peraturan perundang-undangan, dalam hal ini sistem dan prosedur penerimaan pendapatan di badan pengelola keuangan dimulai dari tahap pencatatan penerimaan pendapatan oleh pihak terkait yaitu OPD, bendahara penerimaan dan bagian pembukuan/akuntansi, kemudian dibuat laporan pertanggungjawaban atas penerimaan PAD, yang akan digunakan untuk melakukan verifikasi dan penyetoran kepada bank, dari langkah langkah tersebut maka akan dinilai apakah pelaksanaan penerimaan PAD telah sesuai- dengan peraturan pemerintah No.12 tahun 2019 dimulai dari tahap pencatatan penerimaan, pembuatan laporan, verifikasi sampai tahap penyetoran dalam melakukan penerimaan PAD pada badan pengelolaan keuangan dan aset daerah kota Palembang.

Penerimaan PAD dibadan pengelolaan keuangan dan aset daerah kota Palembang sudah berjalan baik dengan peraturan pemerintah yang terbaru atau belum dilaksanakan karena belum paham akan perubahan peraturan yang diterapkan.

Pendapatan asli daerah yang merupakan wewenang OPD untuk mencatat dan melaporkannya dalam laporan realisasi anggaran, sedangkan penyusunan laporan realisasi anggaran PPKD sebagai kantor pusat, disusun setiap semester/tahunan.

Pendapatan daerah diakui dan diatur dalam PP.N0 12 Tahun 2019 tentang standar akuntansi pemerintah dan penerimaan kas/pendapatan daerah berbasis akrual pada pemerintah daerah dikelompokan menjadi tiga kelompok yaitu : Kelompok pertama yaitu pendapatan asli daerah, Kelompok kedua yaitu pendapatan transfer, Kelompok ketiga yaitu lain-lain pendapatan yang sah.

Prosedur pendapatan di OPD diperoleh dari pendapatan asli daerah, seperti pajak daerah, dana perimbangan, pendapatan hibah dan pendapatan non operasional. Berdasarkan PP NO.12 Tahun 2019 , fungsi akuntansi OPD yaitu mencatat Estimasi pendapatan dengan acuan total anggaran pendapatan terhadap penerimaan dan pengeluaran kas sebagai estimasi biaya belanja daerah.

Dari pengertian tersebut fungsi akuntansi OPD sangat penting dalam pengambilan keputusan sebagai acuan untuk estimasi biaya belanja daerah dimasa yang akan datang atau tahun anggaran baru, setiap estimasi yang dikeluarkan akan menjadi bahan pertimbangan kedepannya berdasarkan fungsi akuntansi OPD yang berlaku sekarang. 


\section{B. KAJIAN TEORI}

\section{1) Definisi Sistem Dan Prosedur Pendapatan Asli Daerah}

Menurut Mahmudi (2011:224), Sistem dan prosedur penerimaan asli daerah adalah serangkaian proses mulai dari pencatatan, penggolongan dan peringkasan transaksi atau kejadian keuangan serta pelaporan keuangan dalam rangka pertanggung jawaban pelaksanaan APBD yang berkenaan dengan penerimaan kas pada OPD/PPKD yang dapat dilaksanakan secara manual maupun komputerisasi.

Dari pengertian diatas, dapat disimpulkan bahwa sistem dan prosedur akuntansi penerimaan asli daerah merupakan sistem yang bertujuan untuk mengumpulkan dan memproses data transaksi penerimaan keuangan daerah sehingga dapat menghasilkan informasi yang dapat digunakan dalam pengambilan keputusan.

\section{2) Sistem}

Menurut Diana dan Setiawati (2011:3), Sistem merupakan serangkaian bagian yang saling bergantung dan bekerja sama untuk mencapai tujuan tertentu.

Menurut Mulyadi (2013:5), mendefinisikan sistem merupakan suatu jaringan prosedur yang dibuat menurut pola yang terpadu untuk melaksanakan kegiatan pokok perusahaan.

Dari definisi diatas maka sistem adalah rangkaian yang dibuat untuk melaksanakan dan merealisasikan tujuan pokok dengan pola yang saling berhubungan.

\section{3) Prosedur}

Menurut Mulyadi (2013:5), Prosedur adalah suatu urutan kegiatan klerikal, biasanya melibatkan beberapa orang dalam satu departemen atau lebih, yang dibuat untuk menjamin penanganan secara seragam transaksi perusahaan yang berulang ulang.

Menurut Irra crisyanti (2011:143), Prosedur adalah tata cara kerja yaitu rangkaian tindakan, langkah atau perbuatan yang harus dilakukan oleh seseorang dan merupakan cara yang tetap untuk dapat mencapai tahap tertentu dalam hubungan mencapai tujuan akhir.

Dari ungkapan diatas maka dapat di definisikan Prosedur adalah urutan atau tahapan kegiatan yang mencakup langkah, tindakan yang harus dilakukan dalam melaksanakan kegiatan pokok depertemen, agar memudahkan proses pengerjaan dalam entitas.

\section{4) Pendapatan Asli Daerah}

Menurut Erlina (2015:111), Pendapatan asli daerah adalah pendapatan yang diperoleh dari pajak daerah, retribusi daerah, hasil pengelolaan kekayaan daerah yang dipisahkan, dan lain-lain pendapatan daerah yang sah.

Menurut Halim (2012:101), Pendapatan asli daerah adalah pendapatan yang berasal dari hasil asli ekonomi daerah tersebut.

Dari definisi diatas maka dapat diartikan bahwa pendapatan asli daerah merupakan penghasilan yang didapatkan langsung dari ekonomi dan sumber pendapatan daerah seperti pajak daerah, retribusi daerah, hasil pengelolaan kekayaan alam di daerah, dan lain-lain pendapatan daerah yang sah

\section{5) Sumber Pendapatan Asli Daerah}

Pendapatan yang berasal dari daerah merupakan penghasilan yang mutlak harus diambil dan dikelola dengan baik dan harus sesuai dengan peraturan pemerintah yang berlaku tanpa harus ada timbal balik dari rakyat kepada 
pemerintah, karena kekayaan yang ada di daerah juga harus dilaporkan dari sumbernya sampai ke hasil dari pengelolaan kekayaan alam atau pendapatan pajak yang di peroleh dari retribusi dan pendapatan lain yang sah.

Adapun sumber pendapatan asli daerah terdiri dari:

$>$ Pajak Daerah

$>$ Retribusi Daerah

$>$ Hasil pengelolaan kekayaan alam

$>\quad$ Lain-lain pendapatan yang sah

\section{6) Sistem Pendapatan Asli Daerah}

Menurut Erlina (2015:114) sistem pendapatan asli daerah adalah sistem yang dibentuk untuk mempermudah dalam mengalokasikan penerimaan daerah.

Dari definisi diatas, dapat dinyatakan bahwa sistem pendapatan asli daerah adalah rangakaian proses dari penerimaan hingga pengalokasian pendapatan asli dari daerah berdasarkan sistem yang telah dibuat sebelumnya, dalammelaksanakan kegiatan penerimaan pendapatan asli daerah perlu sistem yang terstruktur sehingga alur penerimaan PAD dapat terlaksana sesuai dengan aturan dan proses yang benar, maka penerimaan PAD bias dinilai efektif dan efisien.

\section{7) Prosedur Pendapatan Asli Daerah}

Pendapatan asli daerah diterima oleh bendahara penerimaan di badan pengelolaan keuangan dan aset daerah merupakan bentuk dari kewajiban OPD dalam menjalankan dan tanggung jawab atas terlaksananya anggaran pendapatan dan belanja daerah (APBD), Terkhusus tugas ini dilaksanakan pejabat pembendaharaan daerah untuk merealisasikan anggaran- pendapatan dan belanja daerah dari tahap perencanaan, pelaksanaan, hingga pelaporan pertanggungjawaban APBD.

Pejabat pembendaharaan memiliki fungsi penting dan peran yang sangat diperlukan dalam usaha perealisasian anggaran pendapatan dan belanja daerah, penerimaan PAD memiliki tahapan prosedur yang harus dilakukan ialah: 1) Persiapan buku untuk melakukan pencatatan kegiatan pelaksanaan anggaran. 2) Pencatatan ke dalam buku kas umum dan buku kepala. 3) Pengelolaan tanda dan bukti untuk menyusun surat pertanggungjawaban. 4) Penyimpanan dan dokumentasi uang beserta dokumen.

Dari penjelasan diatas tahapan penerimaan pendapatan asli daerah melalui alur dan proses yang sistematis dan terstruktur sehingga dapat membantu kinerja dari pelaksana pengelola penerimaan PAD dapat berjalan secara efektif dan juga efisien, maka setelah semua tahapan sudah berjalan dengan baik dan sudah sesuai dengan peraturan pemerintah ataupun peraturan menteri serta dinyatakan dalam bentuk buku pedoman pengelolaan keuangan daerah, dapat dikatakan bahwa penerimaan pendapatan asli daerah sudah sesuai dengan pedoman pengelolaan keuangan daerah yang berlaku.

\section{8) Peneliti Terdahulu Yang Relevan}

Peneliti terdahulu yang dapat dijadikan referensi dalam meneliti dikemukakan secara rinci dengan hasil penelitian sebagai berikut:

a. Raisa, dkk, dalam penelitian analisis sistem dan prosedur penerimaan pendapatan asli daerah di dinas pengelolaan keuangan daerah kabupaten sitaro di tahun 2015, dan hasilnya menunjukan bahwa kegiatan penerimaan pad pada dppkad kabupaten sitaro sesuai dengan permendagri no.59 tahun 2007 yang mencakup fungsi terkait dan dokumen yang digunakan. 
b. Karamoy, dalam penelitian yang dilakukan di dinas pendapatan kota manado pada tahun 2013, menunjukan bahwa secara keseluruhan sistem dan prosedur penerimaan kas di dinas pendapatan kota manado sudah memadai.

\section{PROSEDUR PENELITIAN}

\section{1) Objek Penelitian}

Objek penelitian atau tempat pengambilan data Kegiatan penelitian ini dilaksanakan di kantor badan pengelolaan keuangan dan aset daerah kota Palembang jl.merdeka No.1, 22 ilir, kota Palembang, Sumatera Selatan 30131.

\section{2) Jenis Penelitian}

Jenis penelitian yang dipakai dalam penelitian ini adalah jenis peneltian metode deskriptif, yaitu dalam menguraikan bagaimana penerapan sistem dan prosedur penerimaan PAD pada badan pengelolaan keuangan dan aset daerah kota Palembang.

\section{3) Variabel Penelitian}

Variabel penelitian ini menggunakan variabel bebas (independent variable). yaitu kondisi atau karakteristik oleh peneliti- dimanipulasi dalam rangka menerangkan hubungannya dengan fenomena yang diobservasi.

\section{4) Populasi dan Sampel}

Menurut Sugiyono (2015:80) Populasi merupakan objek atau subjek yang mempunyai karakteristik tertentu yang ditetapkan oleh peneliti yang pada akhirnya akan ditarik kesimpulannya. Dari pengertian diatas maka populasi penelitian ini yaitu Badan Pengelolaan Keuangan dan Aset Daerah Kota Palembang.

Untuk menentukan sampel yang akan diterapkan ada dua teknik sampling yang bisa digunakan yaitu probability sampling dan non probability sampling.

Dari uraian diatas peneliti menggunakan teknik non probability, yaitu pengambilan data kepada responden yang ahli dibidangnya, dan sampel dari penelitian ini yaitu sistem dan juga prosedur penerimaan pendapatan asli daerah yang ada di badan pengelolaan keunagan dan aset daerah kota Palembang.

\section{5) Sumber Data}

Menurut Sugiyono (2012:193) Data adalah keterangan mengenai segala fakta dan angka yang dapat dijadikan bahan untuk menyusun suatu informasi dan berupa himpunan fakta, angka, grafik, tabel, gambar, lambang, kata, huruf-huruf yang menyatakan sesuatu pemikiran, objek, serta kondisi dan situasi.

Jenis data dibedakan menjadi dua yaitu:

a) Data primer

Data primer adalah data yang langsung memberikan data kepada pengumpul data atau data yang diperoleh langsung dari obyek yang diteliti(lokasi penelitian).

Data primer yang digunakan dalam penelitian ini adalah wawancara peneliti dengan karyawan badan pengelolaan keuangan dan asset daerah kota Palembang.

b) Data sekunder

Data sekunder adalah sumber yang tidak langsung memeberikan data kepada pengumpul data. Data ini biasanya diperoleh dari perpustakaan atau dari laporan-laporan jurnal penelitian terdahulu. 


\section{6) Teknik Pengumpulan Data}

Teknik yang dipakai dalam melakukan penelitian ini menggunakan metode wawancara, dokumentasi dan pengkajian (observasi). Metode ini dipakai untuk mengetahui berapa jauh kesesuaian antara teori yang diterapkan dengan situasi yang terjadi sebenarnya dari objek yang akan diteliti.

\section{7) Teknik Analisis Data}

Menurut Sugiyono (2012:244) analisis data merupakan alat bantu dalam proses menyusun dan menganalisis data bagi peneliti, dalam menyusun hasil yang diperoleh dari wawancara, observasi dan dokumentasi lapangan.

Dalam penelitian ini menggunakan teknik analisis deskriptif kualitatif mengenai metode penerimaan PAD, yaitu data yang di- klasifikasikan dan dianalisis sehingga dapat memberikan gambaran dan keterangan yang lengkap tentang masalah yang diteliti.

\section{HASIL DAN PEMBAHASAN}

\section{1) Hasil Penelitian}

Dari penelitian yang dilakukan penulis, dengan menggunakan teknik analisis deskriptif kualitatif, dan membandingkan kajian terdahulu serta pendapat para ahli juga dari keterangan tabel diatas didapatkan bahwa penerimaan pendapatan asli daerah pada badan pengelolaan keuangan dan aset daerah kota Palembang sudah sesuai dengan pedoman pengelolaan keuangan daerah dan peraturan pemerintah No. 12 Tahun 2019 tentang penerimaan pendapatan asli daerah, metode yang dipakai dalam penelitian ini yaitu metode non probability sampling atau purposive sampling, dimana pengamatan dilakukan kepada responden yang berpengalaman dan memiliki pengetahuan di bidangnya dalam hal ini bidang akuntansi pendapatan asli daerah.

\section{Tabel Alur proses sistem \& Prosedur Penerimaan Pendapatan Asli Daerah} Pada Badan Pengelolaan Keuangan dan Aset Daerah Kota Palembang.

\begin{tabular}{|c|c|c|}
\hline Pelaksana & Langkah & Aktivasi \\
\hline PPKD & 1 & $\begin{array}{l}\text { Memberikan SKP Setelah terbit, kepada bendahara penerima } \\
\text { dan melaksanakan verifikasi saat dilakukan penerimaan } \\
\text { pendapatan. }\end{array}$ \\
\hline $\begin{array}{l}\text { Pihak } \\
\text { pemakai } \\
\text { anggaran } \\
\text { Waiib naiak }\end{array}$ & 2 & $\begin{array}{l}\text { Memberikan atau menyerahkan surat ketetapan retribusi } \\
\text { yang sudah terbit, kepada bendahara penerima pada waktu } \\
\text { bendahara melakukan proses verifikasi penerimaan } \\
\text { pendapatan. }\end{array}$ \\
\hline Wajib pajak & 3 & $\begin{array}{l}\text { Mengambil dan menerima serta mengesahkan laporan } \\
\text { pertanggung jawaban pendapatan dari OPD. }\end{array}$ \\
\hline OPD & 4 & Membayar setoran pajak/ retribusi. \\
\hline & 5 & Melaksanakan verifikasi penerimaan kas dengan SKP/SKR. \\
\hline $\begin{array}{l}\text { Bendanara } \\
\text { penerima }\end{array}$ & 6 & $\begin{array}{l}\text { Mengeluarkan surat buktı pembayaran. } \\
\text { Menyiapkan surat tanda setor. }\end{array}$ \\
\hline & $\begin{array}{l}7 \\
8\end{array}$ & $\begin{array}{l}\text { Melaksanakan pembayaran ke bank dengan disertai surat } \\
\text { tanda setor. }\end{array}$ \\
\hline & 9 & $\begin{array}{l}\text { Surat tanda setor setelah dialokasikan oleh bank, selanjutnya } \\
\text { diterima lagi oleh bendahara penerima sebagai arsip dan } \\
\text { pembukuan }\end{array}$ \\
\hline
\end{tabular}

Sumber : Pedoman Pengelolaan Keuangan Daerah 
Tabel penerimaan pendapatan asli daerah pada badan pengelolaan keuangan dan aset daerah kota Palembang

\begin{tabular}{|l|l|l|l|}
\hline No & Kegiatan & Pelaksana & Keterangan \\
\hline 1 & $\begin{array}{l}\text { Ketersediaan bukti transaksi } \\
\text { penerimaan kas }\end{array}$ & Staff OPD & $\begin{array}{l}\text { Memilah dan } \\
\text { memberikan } \\
\text { nomor urut } \\
\text { bukti STS/R/C } \\
\text { yang diterima } \\
\text { bank }\end{array}$ \\
\hline 2 & $\begin{array}{l}\text { Melakukan register atau } \\
\text { penomoran atas transaksi } \\
\text { penerimaan kas }\end{array}$ & Staff OPD & $\begin{array}{l}\text { Meneliti } \\
\text { keabsahan } \\
\text { bukti STS/R/C }\end{array}$ \\
\hline 3 & $\begin{array}{l}\text { Meneliti keabsahan bukti } \\
\text { STS/R/C }\end{array}$ & $\begin{array}{l}\text { KAsubbid dan } \\
\text { KAbid }\end{array}$ & $\begin{array}{l}\text { Meneliti } \\
\text { dokumen } \\
\text { terkait seperti } \\
\text { STS/R/C }\end{array}$ \\
\hline 4 & $\begin{array}{l}\text { Mengentri data dokumen } \\
\text { STS/R/C ke aplikasi SIMDA }\end{array}$ & $\begin{array}{l}\text { Operator } \\
\text { SIMDA }\end{array}$ & $\begin{array}{l}\text { Pengentrian } \\
\text { data STS/R/C }\end{array}$ \\
\hline 5 & $\begin{array}{l}\text { Membuat jurnal atas transaksi } \\
\text { penerimaan kas }\end{array}$ & $\begin{array}{l}\text { Operator } \\
\text { SIMDA }\end{array}$ & $\begin{array}{l}\text { Mengentri } \\
\text { data ke jurnal } \\
\text { penerimaan } \\
\text { kas }\end{array}$ \\
\hline 6 & $\begin{array}{l}\text { Melakukan rekapitulasi dan } \\
\text { rekonsiliasi }\end{array}$ & $\begin{array}{l}\text { Operator } \\
\text { SIMDA } \\
\text { Kasubbid } \\
\text { Kabid }\end{array}$ & $\begin{array}{l}\text { Melakukan } \\
\text { rekapitulasi } \\
\text { dan } \\
\text { rekonsiliasi }\end{array}$ \\
\hline 7 & $\begin{array}{l}\text { Melakukan posting jurnal ke buku } \\
\text { besar }\end{array}$ & $\begin{array}{l}\text { Operator } \\
\text { SIMDA } \\
\text { Kasubbid } \\
\text { Kabid }\end{array}$ & $\begin{array}{l}\text { Memposting } \\
\text { ke jurnal dan } \\
\text { buku besar }\end{array}$ \\
\hline 8 & $\begin{array}{l}\text { Penyimpanan semua data dalam } \\
\text { Statabase SIMDA OPD dokumen } \\
\text { Kasubbid } \\
\text { Kabid }\end{array}$ & $\begin{array}{l}\text { Pengentrian } \\
\text { data ke dalam } \\
\text { database }\end{array}$ \\
\hline
\end{tabular}

Sumber : Badan Pengelolaan Keuangan dan Aset Daerah Kota Palembang

Sistem dan prosedur penerimaan pendapatan asli daerah digambarkan ke dalam tabel penerimaan pendapatan diatas, berikut penjelasan nya:

1. Sistem penerimaan pendapatan asli daerah dimulai dari staff OPD yang bertugas memilah dan mengurutkan bukti-bukti penerimaan pendapatan asli daerah seperti dokumen surat tanda setor, surat tanda setor retribusi yang diterima bank.

2. Staff OPD yang bertugas memberikan nomor registrasi atas transaksi penerimaan kas daerah atau pendapatan asli daerah.

3. Mengecek keabsahan surat bukti surat tanda setor dan surat tanda setor retribusi, untuk mencegah pemalsuan data.

4. Meneliti dan mengecek kembali keabsahan surat tanda setor yang menjadi bukti dari transaksi, oleh pejabat bidang untuk melakukan pengesahan atas transaksi yang dilakukan, hal ini bias dilakukan oleh pejabat subbidang ataupun langsung kepala bidang untuk sebagai pejabat yang mengetahui. 
5. Mengentri data dokumen surat tanda setor ke aplikasi SIMDA, Yang dilakukan oleh operator SIMDA, Sebagai database penerimaan kas daerah atau penerimaan pendapatan asli daerah.

6. Mengentri dan membuat jurnal untuk transaksi penerimaan kas daerah, dengan menggunakan aplikasi SIMDA, Tugas ini juga dilakukan oleh operator SIMDA setelah itu dlanjutkan dengan pengetrian data ke buku besar atau diposting ke buku besar.

7. Pengecekan dan penilaian kembali oleh pejabat bidang untuk dilakukan rekonsiliasi dan rekapitulasi.

8. Pengentrian data yang telah direkapitulasi dan direkonsiliasi ke dalam database, untuk sebagai dokumen laporan keuangan pemerintah daerah.

Pengarsipan dokumen transaksi berupa surat tanda setor, surat tanda setor retribusi, maupun dokumen terkait lainnya yang menyangkut ke dalam transaksi penerimaan pendapatan asli daerah di badan pengelolaan keuangan dan aset daerah yang dilakukan oleh staff OPD, Dan diketahui oleh pejabat bidang sebagai arsip pemerintah.

\section{2) Pembahasan}

Pada analisis ini, dilakukan pada penerimaan pendapatan asli daerah pada badan pengelolaan keuangan dan aset daerah kota Palembang, analisis ini bertujuan untuk mengetahui dan menilai apakah sistem dan prosedur penerimaan pendapatan asli daerah sudah dilaksanakan sesuai- dengan pedoman pengelolaan keuangan daerah dan peraturan pemerintah terbaru yaitu PP No. 12 Tahun 2019 tentang penerimaan pendapatan asli daerah atau belum, sistem yang digunakan pada penerimaan pendapatan asli daerah adalah berbasis aplikasi keuangan daerah (SIMDA) Yang dikelola oleh staff operator SIMDA di badan pengelolaan keuangan dan aset daerah kota Palembang.

Tabel sistem dan prosedur penerimaan pendapatan asli daerah pada badan pengelolaa keuangan dan aset daerah kota Palembang.

\begin{tabular}{|c|c|c|}
\hline $\begin{array}{c}\text { PP No. } 12 \\
\text { Tahun } 2019\end{array}$ & Hasil penelitian & Keterangan \\
\hline $\begin{array}{l}\text { Fungsi } \\
\text { terkait/bendahara } \\
\text { penerima/OPD }\end{array}$ & $\begin{array}{l}\text { Melakukan pencatatan dalam menerima bukti } \\
\text { surat tanda setor penerimaan pendapatan asli } \\
\text { daerah ke sistem aplikasi keuangan daerah } \\
\text { (SIMDA) }\end{array}$ & Sesuai \\
\hline Aktivitas & $\begin{array}{l}\text { Aktivitas yang dilakukan dalam prosedur } \\
\text { penyerahan bukti penerimaan kas (STS/R/C, } \\
\text { SKP, NOTA Kredit dari bank) yang diterima } \\
\text { oleh staff OPD Dan dibukukan oleh bendahara } \\
\text { penerima, dientri ke aplikasi SIMDA oleh staff } \\
\text { operator dan kemudian di laporkan. }\end{array}$ & Sesuai \\
\hline $\begin{array}{l}\text { Dokumen yang } \\
\text { digunakan }\end{array}$ & $\begin{array}{l}\text { Ada beberapa dokumen yang digunakan yaitu: } \\
\text { 1. Surat Tanda Setor (STS) } \\
\text { 2. Surat Tanda Setor Retribusi (STR) } \\
\text { 3. Surat Ketetapan Pajak (SKP) } \\
\text { 4. Nota Kredit dari Bank. }\end{array}$ & Sesuai \\
\hline
\end{tabular}

Sumber: Data Olahan (2020) 
Dari tabel diatas bahwa proses penerimaan pendapatan asli daerah pada badan pengelolaan keuangan dan aset daerah kota Palembang berawal dari pencatatan penerimaan oleh pihak terkait atau fungsi yang bidang yang berwenang dalam melaksanakan penerimaan pendapatan, pendapatan yang diterima oleh bendahara penerima dicatat dan dientri ke aplikasi keuangan daerah yang terdiri dari surat tanda setoran, surat setoran retribusi pajak, surat ketetapan pajak, dan nota kredit dari bank.

\section{E. KESIMPULAN DAN SARAN}

\section{1) Kesimpulan}

Hasil penelitian dan pembahasan bahwa Sistem penerimaan pedapatan asli daerah pada badan pengelolaan keuangan dan aset daerah kota Palembang telah dijalankan dengan sistem keuangan daerah berbasis aplikasi yang bernama (SIMDA), dan prosedur penerimaan pendapatan asli daerah sudah dijalankan dengan standar operasional prosedur keuangan daerah yang mengacu pada peraturan pemerintah terbaru dan pedoman pengelolaan keuangan daerah, dalam hal ini yaitu penerimaan pendapatan asli daerah yang menjadi point pada penelitian ini, dalam memecahkan masalah yang dihadapi penelitian menggunakan metode analisis deskriptif kualitatif dan pengumpulan data pada penelitian dengan teknik wawancara (interview) dan obsevasi atau melihat langsung fakta yang terjadi di lapangan, dari metode diatas maka kesimpulan yang didapat pada penelitian ini yaitu sebagai berikut:

$>$ Pendapatan asli daerah.

Penerimaan pendapatan asli daerah pada badan pengelolaan keuangan dan aset daerah sudah sesuai dengan peraturan pemerintah nomor 12 tahun 2019 serta pelaksanaan penerimaan pendapatan asli daerah- mencakup fungsi terkait yaitu bendahara penerima, OPD, Bank, dan bagian akuntansi sebagai pembukuan.

> Sistem dan Prosedur Penerimaan Pendapatan Asli Daerah.

Dalam sistem dan prosedur penerimaan pendapatan asli daerah, sudah menggunakan komputerisasi aplikasi keuangan daerah (SIMDA), Sehingga mempermudah pelaksanaan penerimaan pendapatan asli daerah.

\section{2) Saran}

Dari kesimpulan diatas, dikemukakan bahwa penerimaan pendapatan asli daerah sudah dilaksanakan dengan baik dan sesuai dengan peraturan pemerintah terbaru yaitu PP No.12 Tahun 2019 Dan pedoman pengelolaan keuangan daerah, dengan ini penulis memberikan saran yang mungkin bisa menjadi masukan bagi badan pengelolaan keuangan daerah kota Palembang, maupun pihak dan fungsi terkait lainnya yang secara tidak langsung telah terlibat dalam pelaksanaan penerimaan pendapatan asli daerah, dari kesimpulan diatas berikut saran yang dapat diberikan penulis mengenai kekurangan ataupun hal yang perlu ditambah lagi dalam pelaksanaannya :

> Pelaksanaan penerimaan pendapatan asli daerah.

Pelaksanaan penerimaan pendapatan asli daerah sebaiknya selain dicatat di komputerisasi, perlu juga di catat di back up dengan catatan manual, Karena penggunaan data melalui aplikasi beresiko hilang ataupun terkena virus 
computer, selain itu juga pencurian data oleh Hacker juga bisa terjadi akibat kelemahan perlindungan dari aplikasi.

$>$ Peningkatan keahlian/skill kepada pegawai.

Peningkatan skill terhadap pegawai yang mungkin sudah lama bekerja di badan pengelolaan keuangan daerah, agar pelaksanaa program bidang dapat berjalan lebih cepat dan efektif, karena belum tentu semua pegawai lama yang bekerja di badan pengelolaan keuangan dan aset daerah kota Palembang merupakan lulusan yang bisa teknologi, sehingga perlu diadakan program pelatihan pegawai dalam waktu yang telah ditentukan.

\section{DAFTAR PUSTAKA}

Diana, Setiawati. 2011. Sistem informasi akuntansi, perancangan, prosedur dan penerapan. Andi Yogyakarta: Yogyakarta.

Dewi, Irra Crisyanti. 2011. Pengantar ilmu administrasi. PT. Prestasi pustaka raya: Jakarta

Erlina, Omar Sakti, Rasdianto. 2015. Akuntansi keuangan daerah berbasis akrual. Salemba empat: Jakarta.

Halim, Abdul. Iqbal. 2012. Pengelolaan keuangan daerah. UPP STIM YKPN: Yogyakarta.

Mahmudi, 2011. Akuntansi sektor publik. UII Press: Yogyakarta.

Mulyadi, 2013. Sistem akuntansi. Salemba empat: Jakarta.

Raisa, Julie, harjanto. 2015. Analisis penerimaan pendapatan asli daerah pada dinas pendapatan pengelolaan keuangan dan aset daerah kabupaten sitaro, (online), (http//ejournal.unsrat.ac.id)

Sugiyono, 2012 . Metode penelitian bisnis. Alfabeta: Bandung.

Sugiyono, 2015. Metode penelitian bisnis. Alfabeta: Bandung. 